CHAPTER 6

\title{
A (more) comparative approach to some Japanese etymologies
}

\author{
Thomas Pellard
}

Chaque mot a son histoire! ('each word has its own history'). Such was the battle cry of dialectologists and other partisans of the Wellentheorie against the sound laws defended by the Neogrammarians. Though few nowadays would deny the regularity of sound changes and the validity of the comparative method, it remains true that recovering the history of words is often akin to detective work, and that the above maxim seems to be valid in the domain of etymology.

Studies on the genetic relationship of Japanese with other languages have usually been based on lexical evidence foremost, which obviously poses problems if indeed each word has its own history. The search for external cognates of Japanese etyma cannot be limited to the comparison of attested written forms but requires a thorough reconstruction of the internal history of the languages involved as a preliminary step. In the Japonic domain, important advances have been made by John Whitman (e.g., 1985, 1990, 2008, Frellesvig \& Whitman 2004, 2008a), whose work still forms the base of most studies on both the internal and external history of Japonic.

It seems now widely accepted that the examination of the 8th century Old Japanese (OJ) texts needs to be supplemented by taking into account the data from the different Japanese dialects as well as the Ryukyuan and Hachijō languages (Frellesvig \& Whitman 2004, 2008a, Vovin 2010: 3-7, Whitman 2012: 25, Pellard 2008, 2013). Still, few works on Japanese etymology have tapped the rich mines of such 'peripheral' data. One notable exception is for instance the illuminating discussion of the history of personal pronoun shifts in Japonic (Whitman 1999).

Along the same lines, I will propose a more comparative approach to Japanese etymology and give some more examples of how the Ryukyuan data, and to a lesser extent the data from Ainu borrowings, can clarify our knowledge of the (pre)history of the Japanese language. ${ }^{1}$

1 All transcriptions of modern languages have been converted to standard IPA notations. 
Frellesvig \& Whitman (2008a) accept the reconstruction of a mid-vowel * $e$ in Proto-Japonic (PJ), as first proposed by Hattori (1976). ${ }^{2}$ Though most of the supporting data comes from Ryukyuan, they adduce several examples of $\hat{e} / e$ $\hat{\imath} / i$ alternations within oJ which might constitute further evidence of a vowel raising process ${ }^{*} e>\hat{\imath}$ in pre-OJ. ${ }^{3}$

One of such examples adduced by Frellesvig \& Whitman (2008a: 25) is OJ $y e$ 'placenta', which they propose to relate to $i$ in irö 'of the same mother' by vowel raising in non-final position. The root $(y) e$ is itself scarcely attested in Japanese and it does not actually appear in the OJ corpus proper, but only as a Late Middle Japanese reading tradition of the character 胞 'womb, afterbirth' in the Nihon shoki. The first bona fide attestation is in the Shinsen jikyō (898-901) in the gloss Konoye 子乃兄 for the Chinese word 膜 'membrane' (Tenchi I: v14), but the syllables $e$ and $y e$ are sometimes not faithfully distinguished in that source (Hashimoto 1950: 208), so that a doubt subsists as to whether this word was actually $e$ or $y e .^{4}$ It is probably related to the later form ena 'afterbirth', which is only attested after the merger of the syllables $e$ and $y e$.

The Ryukyuan words for 'placenta, amnion, afterbirth' point to a different scenario than that suggested by Frellesvig \& Whitman. Northern Ryukyuan forms such as Izena Píjà, Ie-jima Pìjá, Nakijin Pìjá: or Shuri Píjá do not generally exhibit a loss of the initial vowel to ?j- and thus point to a proto-form *eja A, with a mid-vowel. On the other hand, Southern Ryukyuan forms such as Hirara ${ }^{z} i z a$ or Sawada $/ l a$ exhibit a liquid and obstruentization of the first vowel, which requires us to reconstruct *ira, with a high vowel. The Northern Ryukyuan forms can be reconciled with the Southern ones if we posit for the former two phonetically motivated, though irregular, changes: progressive palatalization *ira > $i j a$, and then height assimilation *ija > eja. Deriving Southern Ryukyuan *ira from *eja would on the other hand require to posit less natural changes. ${ }^{5}$

Though a development * $(j)$ ena $>\mathrm{PR}$ *ira might be not completely impossible,

Proto-Ryukyuan (PR) tone categories are noted by the letters A, B, C. In addition to the references given in the bibliography, I have used my fieldwork notes on Kamikatetsu, Yuwan, Shodon, Okazen, Yoron, Ōgami, and Yonaguni. Japanese prose texts are referred to by volume and page number of the relevant critical edition, or in the case of a fac-simile edition by the name of the manuscript followed by volume, recto/verso, and folio number.

2 See also Pellard (2008, 2013).

3 See Pellard 2010 for further comments.

4 The merger of the two syllables $e$ and $y e$ was completed by the first half of the 1oth $\mathrm{c}$.

5 A form ija is recorded in the Nippo jisho (1603-1604) for several Kyūshū dialects, and it can also be reconciled with the Ryukyuan data by positing a similar $r$-yodization after ${ }^{*} i$. 
$(y) e$ could also be the result of the contraction of *ira, by medial $-r$ - loss ((Whitman 1985: 22-25), Whitman 1990), "Whitman's Law", with the usual subsequent crasis of *ia into palatal $\hat{e} / e$. The comparison is then even clearer with the root attested in many oJ terms for siblings born of the same mother, e.g. irö-n${ }^{n}$ ö 'lesser sibling', irö-mô 'younger sister', irö-ne 'elder sibling', irö-se 'brother.6

The semantic link between 'afterbirth' and 'sibling' is not surprising, and the case of Greek $\alpha \dot{\delta} \varepsilon \lambda \varphi \rho^{\prime} \varsigma$ 'brother' (lit. 'of the same womb') immediately comes to mind. The Chinese words bāo xiōng 胞兄 'elder brother of the same parents' (lit. 'womb/afterbirth-brother') and bāo mèi 胞妹 'younger sister of the same parents' (lit. 'womb/afterbirth-sister') are an even closer parallel. The possibility of a link between the root *ira *ira and oJ ye 'elder brother' may also be envisaged, since oJ ye is a 1.2 noun, that is to say of the high register, and $\mathrm{PR} *$ ira is probably an A-tone word, which corresponds to the Japanese high register.

It is further possible to compare PJ *ira *ir with the Ainu root ir '(be) sibling, though the direction of the borrowing is not clear. The Ainu root, even though it does not occur alone, is found in many words denoting siblings and relatives of the same age, like in ir-utar 'siblings and cousins', ir-okkayo 'brothers', irwak 'siblings and other relatives of similar age' in the Saru dialect.

Both the Kojiki and the Nihon shoki relate the myth of the god Izanagi going after his deceased wife Izanami in the land of the dead (Yomi). Besides its striking similarities with the Greek myth of Orpheus, this tale contains a linguistic puzzle.

Having found his wife in the land of the dead, Izanagi breaks the taboo by looking upon her corpse and flees, terrified by what he saw. Then, he is pursued by a thousand five hundred army until he reaches a place called Yömo-tu-pira-saka, the limit between the land of the living and that of the dead, and manages to escape by pulling a giant rock to obstruct the passage.

In the Kojiki, the toponym is written 黄泉比良坂 (I: 66), with only the part pira written phonographically, while the Nihon shoki has both a logographic notation 泉津平坂 (I: 14, 16) and a phonographic spelling yömo-tu pira-saka

6 We might also add ira-tu-mê 'my lady', with the usual $a \sim \ddot{o}$ alternation, as suggested by Jōdaigo jiten henshū iinkai (1967: 105). This word is actually an honorific used for non-relatives, but the use of kin terms as honorifics for non-relatives is cross-linguistically common (e.g. Chinese, Korean, Japanese, etc.). 
余母都比羅佐可 (I: 16). The word pira-saka is surprising, since the semantic spelling of the Nihon shoki clearly means 'flat slope/hill', and the root pira is indeed well attested in Japanese with the meaning 'flat'. The same oxymoron is seen in other toponyms such as PÎRA-YAMA 'flat mountain' (平山, MYs 9.1715), PÎRA-WOKA 'flat hill' (枚岡 Norito 394, 比良乎加 Wamyō ruijushō Genna VI-v6).

Obviously, all of these instances of pira-X cannot mean 'flat $X$ '. A quick survey shows that this etymon (usually çira ${ }^{7}$ ) is used in dialects all over Japan to designate the slope or side of a mountain or of a hill, a hill, a plateau, or a cliff. Turning to the Ryukyuan languages, the same meanings are attested for this etymon, and a PR form *pira (A), and PJ *pira 2.1/2, can be reconstructed from the following forms: Yamatohama çira 'road over a mountain pass', Kamikatetsu çirá 'slope at the top of a mountain', Yoron pja:, Izena фírár, Nakijin p’jár, Shuri фírà, Ishigaki $p^{s}$ s̀á 'slope', Taketomi pica 'slope (of a roof)'.

Nevertheless, the relationship with *pira 'flat' cannot be easily eluded since the two are homophonous and share the same tone category: Yamatohama çira-

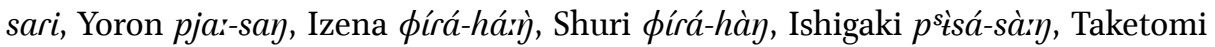
picə-səy. The relationship between 'hill, slope' and 'flat' is not obvious, but I propose that 'flat' is the original meaning of *pira and that the sense 'hill, slope' is a secondary development through 'mountain pass, plateau.'

A mountain pass is a less steep and lower road between two slopes, hence the extension of *pira 'flat' to 'flat place (along a mountain road).' The derivation 'flat' > 'plateau' is also a natural one. The subsequent extension to 'slope', 'hill', 'hill or mountain side,' 'cliff is easily understood as these are what naturally surround a mountain pass or a plateau. A typological parallel can be found in the relationship of Bulgarian планина, Czech planina and Serbo-Croatian planina 'mountain' with Latin plānus 'plain, flat' (Buck 1949: 28).

This reconstructed meaning agrees well with the symbolic value of pirasaka in the Japanese myth. Like a mountain pass is a pathway between two mountains or valleys, pira-saka represents the border and pathway between the world of the living and that of the dead, and it is made impossible to freely pass through by Izanagi precisely when the two divinities put in motion the cycle of life and death for humans.

Interestingly, Ainu has a word pira meaning 'cliff, and also a verb pirasa 'to spread out'. The phonological and semantic match with Japonic *pira is perfect and could hardly be a coincidence. The Japonic word might also be compared to Middle Korean (MK) pilé piléy 'cliff, bank', for which it might be a better

7 Some dialects exhibit a form hera instead, which might be related to the toponym pêraSAKA 幣羅坂 mentioned in the Kojiki (II: 182). However, the Ryukyuan evidence clearly points to earlier ${ }^{*} i$ and not ${ }^{*} e$ in the first syllable. 
match than oJ pê 'edge, bank, vicinity' (Whitman 1985: 151).

This etymology also illuminates another passage of the Kojiki, where the goddess Amaterasu is depicted as 'attaching a five-hundred-arrow quiver to [her] pira' (比良邇者附五百入之靫, I：74). Commentators do not agree on the meaning of this pira, but it most probably means here 'flank' and is thus related to the gloss fira 2.2 for 方 'side' in the Ruiju myōgishō (Kanchiin Sō-chū: v18). ${ }^{8}$ The same meaning 'side, direction, vicinity' is attested in many Japanese and Ryukyuan dialects, e.g., Tottori attci-bira 'other there', Yoron mici-bja: 'North direction', Yamatohama hata-çira, Nakijin hàtà-ppjá: 'one side, one direction'. Further semantic extensions include Ōita kawa-n-hera 'river shore' or Hachijō çira 'border of a hearth, hearthside.' The semantic path is here 'flat' > 'surface, face' > 'flank, side' > 'direction, vicinity' and is partly paralleled by the evolution of Latin costa 'rib, side' and related words into French côte 'coast, seashore, slope', coteau 'small hill' or côté 'side, along, vicinity'.

There are also deeper implications for the reconstruction of earlier Japanese: compounds of the type pira-X, such as pira-saka, pîra-yama, pira-woka, do not mean 'flat $X$ ' and are thus not of the modifier-head type $(+[\operatorname{Adj}[\mathrm{N}]])$. The element pira is a noun meaning 'pass, side' modified by the following noun which restricts its denotation ('pass or side of $X$, $[[\mathrm{N}] \mathrm{N}]$ ). This also explains how Izanagi managed to block the pira-saka of the land of the dead: it was not a saka, a slope or hill, but a pira, a pass.

Such compounds thus have a head-modifier structure, which is unexpected since all Japonic languages are consistently head-final. Considering also that OJ has a system of prefixes, which is uncommon for a verb-final language, this disharmony could suggest the possibility that pre-OJ underwent some important syntactic changes. This resonates with some recent work on alignment and word order in OJ (Vovin 2009: 589, 661, 1055-1056, Yanagida \& Whitman 2009).

\section{$3 \quad$ Revisiting some Koreo-Japonic comparisons}

The seminal dissertation of Whitman (1985) remains the most thorough work on the genetic comparison of Korean and Japanese. It presents a corpus of more than 300 morphological and lexical comparisons supported by a set of detailed sound correspondences, amended in Frellesvig \& Whitman (2008a)

8 The character 靫 usually stands for $y u k \hat{\imath}$, a quiver traditionally worn on the back, but since Amaterasu is said to already have a thousand-arrow quiver on her back (負千入之靶) and since the five-hundred-arrow quiver is said to be 'attached' (附), in contrast to the first one which is explicitly said to be 'worn on her back' (負), it is reasonable to assume that she wore the second quiver on her side. 
and Whitman (2012). Vovin (2010) tackles the painstaking task of reviewing every comparison proposed by Whitman (1985) and rejects most of them as being probable borrowings or chance resemblances. A reexamination of every proposed etymology is far beyond the scope of this contribution, ${ }^{9}$ but I wish to offer some comparative perspectives from a Ryukyuanist point of view.

One of the main methodological principles of Vovin (2010: 6) is that in order to be reconstructed in $\mathrm{PJ}$, an etymon has to be attested in OJ or MJ and Southern Ryukyuan, or in Ryukyuan and a non-Central Japanese dialect. From this follows that any Koreo-Japonic comparison without a (Southern) Ryukyuan cognate is likely to be a loan from Korean to Japanese. ${ }^{10}$

I will adduce below Ryukyuan comparanda for several comparisons rejected by Vovin. ${ }^{11}$ It might thus be possible to retrieve some of the Koreo-Japonic comparisons proposed by Whitman (1985), provided that they do not pose other problems than their lack of attestation in Ryukyuan. I will nevertheless remain agnostic as to their interpretation. In other words, my aim is to show that the following words need to be reconstructed at the PJ level, but whether they constitute cognates, borrowings or chance similarities with Korean remains to be discussed.

\subsection{Morning}

The comparison oJ asa :: $\mathrm{MK}$ àchóm 'morning' (Whitman 1985: 244, \#321) is known since at least Polivanov (1891-1938), but seems to lack Ryukyuan cognates at first sight (Vovin 2010: 224). Indeed, the usual word for 'morning' in virtually every Ryukyuan variety is not related to asa: Shodon sika:ma, Okazen sitt̀múttì, Yoron sikámà, Nakijin sitimítit, Shuri sútúmití, Ōgami stumuti, Ishigaki stitúmúdí, Yonaguni t’ùmútî.

Still, a cognate of asa can be found in many compounds, which more often than not do not exist as such in Japanese and thus cannot be loanwords: Yamatohama Pasa-çikjari 'glow in the morning sky', ?asa-sikama 'early morning', Pasa-t ${ }^{h}$ eda 'morning sun', Shodon Pasa-jiihs: 'glow in the morning sky', Yoron àsá-6ù 'morning tide, Izena Pàsà-ùì 'morning rain', Pásá-ùtài 'morning fatigue', Pásá-zúrì 'morning meeting', Nakijin hàsàs-ní 'morning sleep', hàsàs-toijù 'morning

9 See Whitman (2012) for a response on some etymologies.

10 I will not discuss the potential problems of this approach in the case of a family like Japonic, where there are only two main branches, but accept it as valid for the sake of the discussion.

11 I will restrict myself to etyma well attested in Ryukyuan and will not address intriguing but isolated attestations such as wat ${ }^{h}$ a-ganaci 'sea god' (Yamatohama), which might be added to the comparison OJ wata 'sea' :: MK pàtáh pàlól 'id.' (Whitman 1985: 213, Vovin 2010: 111). 
dew', Ie-jima Pásá-úki 'early rising', Pásá-gánnjái 'morning thunder', Pásá-dúrì 'morning calm, Shuri Pásá-gúmúi 'cloudy morning', ?ásá-dátcí 'early morning, Ōgami asa-munu 'breakfast', Ishigaki ásá-útsé 'during the morning', ásá-páná 'early morning', ásá-bìrt̀ 'morning defecation', Taketomi asə-uzumi 'morning rising', asa-tui 'morning rooster', asa-ningai 'morning prayer', Yonaguni asadusay 'morning and evening.'

It is thus possible to reconstruct PR *asa B, and PJ *asa $2.5 \mathrm{~b}$ 'morning' from the comparison with Japanese asa 2.5 .

\subsection{Body}

The comparison of oJ mu- mï 'body' with MK mwóm 'id.' (Whitman 1985: 237, \#259) is well known and is one of the core etymologies of Koreo-Japonic comparative studies. It is nevertheless rejected by Vovin (2010: 194) on the sole basis of its lack of attestation in Ryukyuan.

However, as already noticed by Whitman (2012: 32), a cognate is attested in Ryukyuan as a pronoun. Whitman quotes the Nakijin form ?àgá:mi 'we', to which we can add Yoron $m \check{r}:$ 'self. Such examples parallel the grammaticalization of oJ mï into Early Middle Japanese wagami 'I, he, himself' and $m i$ 'I'.

Even clearer, non-grammaticalized cognates are also found, with the meaning 'edible flesh of fish and other animals, especially the muscular tissue, edible part of seashells and sea urchins, human flesh,' 'pulp, flesh of fruits, fruit', and by extension 'substantial, solid ingredient in a soup': Yamatohama mi: 'fruit, flesh', Yuwan mi: 'flesh of seashells', Shodon mî̀ 'fruit, flesh', Okazen mí: 'fruit, flesh', Izena mí: 'fruit, flesh', Shuri mî: 'fruit, content', Ōgami mim 'meat, flesh', Ishigaki $m \hat{t}:$ 'flesh, fruit, ingredient', Taketomi $m i:$ 'ingredient, meat, body', Yonaguni mí: 'flesh, ingredient'.

The reconstruction of $\mathrm{PR}$ * $m i \mathrm{~A}$ 'body, flesh, meat' and its comparison with Japanese $m u-\sim m \ddot{~} 1.1$ 'body' is rather straightforward. Though the two are traditionally thought to be distinct words, this is clearly the same word as of $m \ddot{i}$ ' 'fruit, seed, kernel, pulp', which also belongs to class 1.1. We thus need to reconstruct only one PJ word here: *mui 1.1 'body, flesh, meat, soft tissue underneath the skin or shell of animals and fruits'.

\subsection{Origin}

The comparison of oJ mötö 'base, bottom, root' with MK mith 'id.' (Whitman 1985: 240, \#278) is argued by Vovin (2010: 202) to be a Korean loan, in spite of its existence in Ryukyuan as a classifier. ${ }^{12}$

12 I rather take the existence of this classifier as evidence for the antiquity of this etymon in Ryukyuan and Japonic. 
It is nevertheless possible to find several varieties which have an independent cognate form: Yamatohama mutu 'origin', Yuwan mutu 'root of vegetables', Okazen mùstú 'origin', Yoron mútù 'origin, classifier for plants', Izena mùstú 'origin', Nakijin mútù 'origin', Ie-jima mútú 'origin, root, trunk', Shuri mústú 'origin', Ikema mutu 'origin', Ōgami mutu 'stem', Ishigaki mútú 'origin', Taketomi mútú 'origin, trunk', Yonaguni mùtû 'origin'

I thus reconstruct $\mathrm{PR}$ *moto $\mathrm{C}$ as a cognate of Japanese mötö 2.3?, and PJ *mata 2.3a 'base, root, origin'.

\subsection{Darkness}

The comparison of oJ yamï 'darkness' with $\mathrm{MK}$ cyèmúl-, cyémkúl '(day) comes to a close, gets dark' (Whitman 1985: 232, \#199) is rejected by Vovin (2010: 169) because of the scarce attestation of this etymon in Ryukyuan and of other irregularities.

However, regular cognates of oJ yamï can be found in all branches of Ryukyuan, though sometimes in compounds only: Yamatohama jami, Okazen jàmí, Nakijin k’ùrár-jàmi, Shuri jámí, Ōgami ffa-jam, Ishigaki jámì 'darkness', Yoron ju-jay, Izena jàmi-gà-jǔr, Ie-jima jú-jáni 'dark night'.

I thus propose to reconstruct $\mathrm{PR}$ *jami $\mathrm{A}$, and from the comparison with Japanese yamï 2.3, PJ *jam $\{u, o\} i$ 2.3b 'darkness'.

\subsection{Seaweed}

The comparison of $\mathrm{OJ} m o \sim m \ddot{e}$ 'seaweed' with $\mathrm{MK}$ mól 'edible seaweed' (Whitman 1985: 237, \#253, Vovin 2010: 193) cannot be rejected as a late loan on the basis that this word has no cognate in Ryukyuan.

This etymon is actually well attested in both Northern and Southern Ryukyuan: Yamatohama $m u^{r}$, Yuwan $m u^{\prime}$, Shodon mô: Okazen múr, Izena mór, Nakijin mór, Ie-jima $m \hat{o}:$, Shuri $m \hat{u}$, Ōgami $m u$, Ishigaki $m o \hat{r}:{ }^{13}$

We can thus reconstruct a PR form *mo A, and from this a form * $m\{0, \partial\} 1.2$ 'seaweed' at the PJ level. ${ }^{14}$

\section{Primary sources}

Keizai zasshisha (ed.). 1915. Kokushi taikei 1 Nihon shoki. http://kindai.ndl.go . jp/info:ndljp/pid/991091. Tokyo: Keizai zasshisha.

13 The vowel $o$ found in some varieties is irregular, but the tonal correspondence is perfect.

14 See also Antonov (this volume). 
Kurano, Kenji \& Takeda, Yūkichi (eds.). 1958. Kojiki Norito. Tokyo: Iwanami shoten.

Kyōto Daigaku Bungakubu Kokugogaku Kokubungaku Kenkyūshitsu (ed.). 1968. Shohon shūsei Wamyō ruijushō. 2 vols. Kyoto: Rinsen shoten.

Nakanishi, Susumu (ed.). 1978-1985. Man'yōshū zen'yakuchū genbun tsuki. Tokyo: Kōdansha.

Ōtsuki, Fumihiko (ed.). 1916. Shinsen jikyō. 7 vols. Tokyo: Rokugōkan. http: //archive.org/details/shinsenjikyotenj078800.

\section{Bibliography}

Buck, Carl Darling. 1949. A dictionary of selected synonyms in the principal Indo-European languages. Chicago: University of Chicago Press.

Frellesvig, Bjarke \& Whitman, John. 2004. The vowels of proto-Japanese. Japanese Language and Literature 38(2). 281-299.

Frellesvig, Bjarke \& Whitman, John. 20o8a. Evidence for seven vowels in protoJapanese. In Frellesvig, Bjarke \& Whitman, John (eds.), Proto-Japanese: Issues and prospects, 15-41. Amsterdam: John Benjamins.

Frellesvig, Bjarke \& Whitman, John (eds.). 20o8b. Proto-Japanese. Amsterdam: John Benjamins.

Hashimoto, Shinkichi. 1950. Kokugo on'in no kenkyū. Tokyo: Iwanami Shoten.

Hattori, Shirō. 1976. Ryūkyū hōgen to hondo hōgen. In Iha Fuyū tanjō hyakunen kinenkai (ed.), Okinawagaku no reimei, 7-55. Tokyo: Okinawa bunka kyōkai.

Izena-jima hōgen jiten henshū iinkai (ed.). 2004. Izena-jima hōgen jiten. 2 vols. Izena-son: Izena-son kyōiku iinkai.

Jōdaigo jiten henshū iinkai (ed.). 1967. Jidaibetsu kokugo daijiten Jōdai hen. Tokyo: Sanseidō.

Kiku, Chiyo \& Takahashi, Toshizō. 2005. Yoron hōgen jiten. Tokyo: Musashino shoin.

Kokuritsu kokugo kenkyūjo (ed.). 1963. Okinawago jiten. Tokyo: Ōkurashō insatsukyoku.

Maeara, Tōru. 2011. Taketomi hōgen jiten. Ishigaki: Nanzansha.

Miyagi, Shin'yū. 2003. Ishigaki hōgen jiten. 2 vols. Naha: Okinawa taimusu.

Miyara, Tōsō. 198o-1981 [1930]. Yaeyama goi. 2 vols. (Miyara Tōsō zenshū vol. 8-9). Tokyo: Daichi shobō.

Nakamura, Yukihiko \& Okami, Masao \& Sakakura, Atsuyoshi (eds.). 1982-1999. Kadokawa kogo daijiten. 5 vols. Tokyo: Kadokawa shoten.

Nakasone, Seizen. 1983. Okinawa Nakijin hōgen jiten. Tokyo: Kadokawa shoten. 
Nevskij, Nikolai A. 2005 [1922-1928]. Miyako hōgen nōto. 2 vols. Hirara: Okinawaken Hirara-shi Kyōiku iinkai.

Osada, Suma \& Suyama, Nahoko. 1977-1980. Amami hōgen bunrui jiten. 2 vols. Tokyo: Kasama shoin.

Oshio, Mutsuko. 1999. Okinawa Ie-jima hōgen jiten. 2 vols. Ie-son: Ie-son kyōiku iinkai.

Pellard, Thomas. 2008. Proto-Japonic *e and *o in Eastern Old Japanese. Cahiers de Linguistique Asie Orientale 37(2). 133-158.

Pellard, Thomas. 2013. Ryukyuan perspectives on the Proto-Japonic vowel system. In Frellesvig, Bjarke \& Sells, Peter (eds.), Japanese/Korean Linguistics 20, 8196. Stanford: CSLI Publications.

Pellard, Thomas. 2010. Review of Bjarke Frellesvig and John Whitman (2008) Proto-Japanese: Issues and prospects. Cahiers de Linguistique Asie Orientale 39(1). 95-114.

Shōgakkan kokugo jiten henshūbu (ed.). 2000-2002. Nihon kokugo daijiten. 2nd edn. 15 vols. Tokyo: Shōgakkan.

Tamura, Suzuko. 1996. Ainugo Saru hōgen jiten. Tokyo: Sōfūkan.

Vovin, Alexander. 2010. Koreo-Japonica: A critical study in the proposed language relationship. Honolulu: University of Hawai'i Press.

Vovin, Alexander. 20o9. A descriptive and comparative grammar of Western Old Japanese. Part 2: Adjectives, verbs, adverbs, conjunctions, particles, postpositions. Folkestone: Global Oriental.

Whitman, John. 1990. A rule of medial *-r- loss in pre-Old Japanese. In Baldi, Philip (ed.), Linguistic change and reconstruction methodology, 511-546. Berlin: Mouton de Gruyter.

Whitman, John. 2008. The source of the bigrade conjugation and stem shape in pre-Old Japanese. In Frellesvig, Bjarke \& Whitman, John (eds.), Proto-Japanese: Issues and prospects, 159-173. Amsterdam: John Benjamins.

Whitman, John. 2012. The relationship between Japanese and Korean. In Tranter, Nicolas (ed.), The languages of Japan and Korea, 24-38. New York: Routledge. Whitman, John. 1999. Personal pronoun shift in Japanese: A case study in lexical change and point of view. In Kamio, Akio \& Takami, Ken-ichi (eds.), Function and Structure, 357-386. Amsterdam: John Benjamins.

Whitman, John B. 1985. The phonological basis for the comparison of Japanese and Korean. Harvard University (Dissertation).

Yanagida, Yuko \& Whitman, John. 20o9. Alignment and word order in Old Japanese. Journal of East Asian Linguistics 18(2). 101-144. 